\title{
CREATIVITY VIS-À-VIS SPEAKING AMONG EXTROVERT AND INTROVERT EFL LEARNERS
}

\author{
Hamid Marashi \\ Islamic Azad University, Central Tehran, Iran \\ E-mail: hamid.marashi@ iauctb.ac.ir \\ Asal Amin-Ranjbar \\ Islamic Azad University, Central Tehran, Iran \\ E-mail: ranjbar6464@yahoo.com
}

APA Citation: Marashi, H., \& Amin-Ranjbar, A. (2018). Creativity vis-à-vis speaking among extrovert and introvert EFL learners. Indonesian EFL Journal, 4(1), 11-22.

Published: 01-01-2018

\begin{abstract}
The study attempts to investigate the relationship between extrovert and introvert EFL learners' speaking skill and their creativity. For this purpose, 40 male introverts, 40 male extroverts, 40 female introverts, and 40 female extroverts were selected among a total number of 180 through their performance on the Eysenck's Personality Inventory. Subsequently, the Abedi-Schumaker Creativity Test and a sample PET speaking test were administered to all 160 participants of the study. The Pearson correlation coefficient was subsequently used to check the correlation between speaking and creativity of each group of extrovert and introvert EFL learners. The results indicated that there was a significant correlation between each group's speaking and creativity. Furthermore, a linear regression was also run to check any predictability pattern. The findings demonstrated that each group's speaking predicted significantly their creativity.

Keywords: creativity, extrovert, introvert, speaking skill
\end{abstract}

\section{INTRODUCTION Speaking}

Speech is arguably the most basic part of human communication. This is perhaps why for most people, speaking a language is synonymous with knowing that language. Despite the speed and excellence with which any given young child acquires this skill in his/her L1, speaking in a second/foreign language is indeed the most demanding of the four skills (Hedge, 2008) with its assessment being also highly challenging (Winke, Gass, \& Myford, 2012, as cited in Bijani \& Khabiri, 2017). No wonder then that the ELT literature is overwhelmed by studies on how to enhance the process of learning to speak in various contexts (e.g. Chuang, 2009; Cope, 2008; Dewaelea \& Furnham, 2000; Kim, 2009; Koosha, Ketabi, \& Kassaian, 2011; Marashi \& Dolatdoost, 2016; Tuan \& Neomy, 2007; Vercellotti, 2015).

There exists a multitude of definitions for speaking; one such is provided by Chaney and Burk (1998, p. 13) where he states that speaking is "the process of building and sharing meaning through the use of verbal and non-verbal symbols, in a variety of contexts." The difference between speaking and other skills is not simply one attributable to the final product as indeed "some of the processing skills needed in speaking differ from those involved in reading and writing" (Ellis, 1994, p. 35).

Thornbury (2005, p. 1), states that, "Speaking is speech production that becomes a part of our daily life". Bringing more detail, Brown (2001) elaborates that there are two basic language functions which students who are trained to speak should recognize: "The first one is transactional function, which means exchange and conveying specific information. And the other is interpersonal function, which is the main purpose to keep social relationships" (p. 273). 
Speaking is incontrovertibly beyond mere linguistic competence as there is perhaps consensus ever since Hymes' (1972) conceptualization of communicative competence that speaking involves the application of many other constructs and composites including strategic competence, discoursal competence, and sociocultural competence (Canale \& Swain, 1980).

Speaking is of course a multifaceted construct which is interrelated with different abilities and skills, one such being creativity (Kellogg, 1994).

\section{Creativity}

Creativity is a human resource employed mainly to address the challenges of psychological and social adaptation and is broken down as a personal attribute, a process, a product, and as the context which enables it (Baer, 2010). As demonstrated empirically through research, creativity does not depend on stable characteristics (Averill, 2004); rather, it is the corollary of individual, behavioral, cognitive, and contextual processes (Amabile, \& Khaire, 2008; Sternberg \& Lubart, 1996).

Creativity and intelligence are at times confused with one another, whereas the two constructs are not necessarily coterminous (Gardner, 2010). Indeed, there are two aspects that define creativity: first is novelty which means that creative work has to be different from previous works and second is quality which - in practical terms - connotes that new products must be suitable and useful for the reference group according to the situation or the problem (Sternberg \& Kaufman, 2010).

As Agars, Kaufman, and Locke (2008, p. 62) put it, "Most early definitions of creativity implied that creativity was a singular entity...These initial conceptualizations, although meaningful, were somewhat limited in their application". Accordingly, Sarsani (2006) transgresses this restriction where he defines creativity as, "the ability or the capacity of a person to discover and explore new areas to create or produce new idea, or theory or object including the arrangement or reshaping of what already exists" (p. 105).
There are factors that can serve as barriers to creativity; according to Davis (1999), these barriers are indeed external or internal blocks "that either inhibit creative thinking and inspiration or else prevent innovative ideas from being accepted and implemented. Most barriers result from learning. They may originate with one's family, peers, community, or educational environment, or from others in the culture ( $\mathrm{p}$. 165). Albeit a rather recent concept of interest in ELT, quite a sizeable number of research studies have been conducted on the stance of creativity in language learning (e.g. Cropley, 2007; Daemi \& Moghimi, 2004; John \& Meera, 2014; Jeffery \& Craft, 2001; Marashi \& Dadari, 2012; Marashi \& Khatami, 2017; Runco, 2004; Sarsani, 2006; Silvia, 2008).

\section{Introversion/Extroversion}

Another aspect which cannot be neglected in exploring into the skill of speaking is personality among which the dichotomy of introversion/extroversion is quite significant. Extroversion and introversion are probably the most researched aspect of personality (Burger, 1993). When comparing introverts and extroverts, "extroverts are harder to condition and the consistency of their conditioned responses are less likely to be seen. Extroverts are more impulsive and when they are learning, punishment does not prove to have any effect on them" (Zuckerman, 2005, p. 208). According to Lucas (2007, p. 335), "Extroversion is a trait which is in comprehensive models of personality, one's interest in social interaction, and it engages excitement-seeking behaviors". MorroneStrupinsky and Lane (2007, p. 1267) also assert that, "Extroversion consists of agentic and affiliative components, which are typified by distinct positive emotional states of positive activation and warmth-affection, accordingly". Introverts, on the other hand, are considerate people by nature but lack the ability to express their feelings. Instead of just blurting out the word, they think before expressing any idea or any feeling they have (Sharp, 1987). Dimler, Goldstein, Kohlberger, and Kim-Prieto (2007) declare that introversion is a personality which is stable 
and heritable and it has a quiet setting. According to Richards and Schmidt (2002, p. 195), "a person who tends to avoid social contact with others and is often preoccupied with his feelings, thoughts, and experience" is considered to be an introvert. "Introverts should be taught how to acquire social skills. They should not be changed in order to match them with other personality types. Introverts enjoy giving lectures and they take advantage of the deductive form of instruction" (Burruss \& Lisa Kaenzig, 1999, p. 21).

Ever since the pioneering works of the German psychologists Hans and Sybil Eysenck in the early 1970s, many studies have been conducted on the language behavior and specifically speaking of extrovert and introvert EFL learners (e.g. Aragon, Johnson, \& Shaik, 2002; Downing, 2010; Ehrman \& Oxford, 1990; Khany \& Ghoreyshi, 2013; Marashi \& Dibah, 2013; Marashi \& Fotoohi, 2017; Thompson, 2012; Zafar \& Meenakshi, 2012).

\section{PURPOSE OF THE STUDY}

Inspired by the studies conducted on speaking and creativity and also being interested in seeing whether the different personality traits of learners would serve as a moderator variable in the relationship of the aforesaid two constructs, the researchers aimed at responding to the following research questions:

1. Is there any significant relationship between extrovert EFL learners' speaking and creativity?

2. Is there any significant relationship between introvert EFL learners' speaking and creativity?

3. Is extrovert EFL learners' creativity a significant predictor of their speaking?

4. Is introvert EFL learners' creativity a significant predictor of their speaking?

\section{METHOD}

\section{Participants}

A total of 160 EFL learners aged between 2025 years took part in this study. This sample comprised of 40 male introverts, 40 male extroverts, 40 female introverts, and 40 female extroverts. The selection was not random and through convenient sampling. These 160 participants were selected from a group of 180 students based on their performance on the Eysenck Personality Inventory. Furthermore, the two researchers participated in the study as the raters of the speaking tests; they enjoyed inter-rater consistency $(\mathrm{r}=0.718, p=0.0001<$ $0.05)$.

\section{Instruments}

There are three instruments used in this research, namely speaking test, Eysenck Personality Inventory (EPI), and AbediSchumacher Creativity Test (ACT).

A sample speaking paper of the Preliminary English Test was used in this study. The test lasts from 10 to 12 minutes. Two candidates sit for the test simultaneously and the test is assessed by two examiners: one, the interlocutor, talks to the candidates, and the other, the assessor, just listens. The test has four parts. In first part, candidates interact with an examiner. In parts two and four, they interact with another candidate and in part three, they have an extended individual long turn. The test focus on assessing candidates' ability to express themselves in order to carry out functions as threshold level, to ask and to understand questions, to make appropriate responses, and to talk freely on matters of personal interest. Candidates are assessed on their performance throughout the test. There are a total of 25 marks in this paper.

The EPI (Eysenck, Eysenck, \& Barrett, $1985)$ is a questionnaire to assess the personality traits of a person. It is a validated test consisting of $57 \mathrm{Yes} / \mathrm{No}$ items which conceptualize personality as two biologicallybased categories of temperament which include: extroversion/introversion and neuroticism/stability. The test provides the testees with three different scores: the E score which is related to how much extrovert a person in, the $\mathrm{N}$ score measuring the neuroticism, and the lie score which tries to measure how socially desirable a person has wanted to prove to be. The $\mathrm{E}$ score is computed out of 24 since it consists of 24 items, the $\mathrm{N}$ score is out of 24 , and the lie score is out of nine. The yes/no answers 
should be given based on the usual way of acting or thinking of an individual. This is a standardized psychological test, the reported reliability and concurrent validity indices of which are 0.89 and 0.79 , respectively

(Shackleton \& Fletcher, 1984).

The ACT was designed by O'Neil, Abedi, and Spielberger in 1992 and consists of 60 multiple-choice items used for establishing the scores of the four traits underlying creative thinking. Accordingly, the test is divided into the four subscales of: fluency (22 items), flexibility (11 items), originality (16 items), and elaboration (11 items). Each item has three options ranging from least to most creative response with a range of scores between 0-2. Therefore, the ultimate score is estimated in the possible range of 0 to 120 and participants are supposed to answer the items in 30 minutes.

\section{Procedure}

To begin with, the researchers administered the EPI to 180 EFL learners to find 160 participants (as detailed in the participants section). The researchers explained in Farsi the purpose of the study and asked the participants to take part only if they are willing and thus refrain from responding to the items precariously. Once the participants were selected, the researchers gave them the PET speaking section followed by the ACT.

Naturally, it was not possible to conduct the speaking test for 160 participants on the same day; hence, the test was administered on several days with different number of participants on each day with respect to availability. Both the speaking and the creativity tests, however, were administered subsequently on each day in order to prevent the risk of subject mortality.

\section{RESULTS \\ Descriptive Statistics \\ Speaking Test}

Once the 80 extrovert and 80 introvert learners were selected, the researchers administered the speaking test. Table 1 below displays the descriptive statistics of the speaking test.

Table 1. Descriptive statistics of the scores of the participants on the speaking test

\begin{tabular}{lccccccc}
\hline & $\mathrm{N}$ & Minimum & Maximum & Mean & $\begin{array}{c}\text { Std. } \\
\text { Deviation }\end{array}$ & Statistic & $\begin{array}{c}\text { Std. } \\
\text { error }\end{array}$ \\
\hline $\begin{array}{l}\text { Speaking } \\
\begin{array}{l}\text { Valid N } \\
\text { (listwise) }\end{array}\end{array}$ & 160 & 12 & 25 & 19.84 & 3.635 & -.354 & .192 \\
\hline
\end{tabular}

As is seen in the above table, the mean and the standard deviation were 19.84 and 3.63 , respectively. The scores represented normalcy with the skewness ratio falling within the \pm 1.96 ratio $(-0.354 / 0.192=-1.84)$.

Table 2 below shows the descriptive statistics of the above scores disaggregated by introverts and extroverts. As is seen in the table below, the mean and the standard deviation of the extroverts' speaking scores were 19.74 and 3.64 , respectively, while those of the introverts were 19.94 and 3.65, respectively. Furthermore, the scores represented normalcy $(-0.389 / 0.269=-1.446$ and $-0.328 / 0.269=-1.219)$.

\section{Table 2. Descriptive statistics of the introverts and extroverts on the speaking test}

\begin{tabular}{lccccccc}
\hline & & & & & \multicolumn{2}{c}{ Std. } & \multicolumn{2}{c}{$\begin{array}{c}\text { Skewness } \\
\text { D }\end{array}$} & Min & Max & Mean & Statistic & $\begin{array}{c}\text { Stror } \\
\text { erron }\end{array}$ \\
\hline Extroverts' Speaking & 80 & 12 & 25 & 19.74 & 3.640 & -.389 & .269 \\
Introverts' Speaking & 80 & 12 & 25 & 19.94 & 3.649 & -.328 & .269 \\
Valid N (listwise) & 80 & & & & & & \\
\hline
\end{tabular}




\section{Creativity Test}

Following the speaking test, the researchers administered the creativity test. Table 3 below displays the data. As is seen in the above below, the mean and the standard deviation were 75.65 and 28.92 , respectively. The scores represented normalcy $(0.267 / 0.192=1.39)$.

Table 3. Descriptive statistics of the participants' scores on the creativity test

\begin{tabular}{lccccccc} 
& N & Minimum & Maximum & Mean & $\begin{array}{c}\text { Std. } \\
\text { Deviation }\end{array}$ & Statistic & $\begin{array}{c}\text { Std. } \\
\text { error }\end{array}$ \\
\hline $\begin{array}{l}\text { Creativity } \\
\text { Valid N } \\
\text { (listwise) }\end{array}$ & 160 & 21 & 181 & 75.65 & 28.923 & .267 & .192 \\
\hline
\end{tabular}

Table 4 below shows the descriptive statistics of the above scores disaggregated by introverts and extroverts. As is seen in the table below, the mean and the standard deviation of the extroverts' creativity scores were 72.99 and 27.90 , respectively, while those of the introverts were 75.15 and 26.68 , respectively. Furthermore, the scores represented normalcy $(0.054 / 0.269=0.200$ and $0.465 / 0.269=1.728)$.

Table 4. Descriptive statistics of the introverts and extroverts on the creativity test

\begin{tabular}{|c|c|c|c|c|c|c|c|}
\hline & \multirow[b]{2}{*}{$\mathrm{N}$} & \multirow[b]{2}{*}{ Min } & \multirow[b]{2}{*}{ Max } & \multirow[b]{2}{*}{ Mean } & \multirow[b]{2}{*}{$\begin{array}{c}\text { Std. } \\
\text { Deviation }\end{array}$} & \multicolumn{2}{|c|}{ Skewness } \\
\hline & & & & & & Statistic & $\begin{array}{l}\text { Std. } \\
\text { error }\end{array}$ \\
\hline Extroverts' creativity & 80 & 21 & 178 & 72.99 & 27.902 & .054 & .269 \\
\hline Introverts' creativity & 80 & 25 & 181 & 75.15 & 26.680 & .465 & .269 \\
\hline Valid N (listwise) & 80 & & & & & & \\
\hline
\end{tabular}

\section{Responding to the Research Questions First Research Question}

To respond to the first question, i.e. whether a significant relationship existed between extrovert learners' speaking and creativity, the Pearson Correlation Coefficient were run. Prior to this, the assumptions for running this parametric test had to be checked, i.e. normality, linearity, and homoscedasticity of the two distributions of scores. Normality of all sets of scores had already been established (see above). To inspect the second parameter (linearity), the researchers used a scatterplot of the two variables of the study (Figure 1).

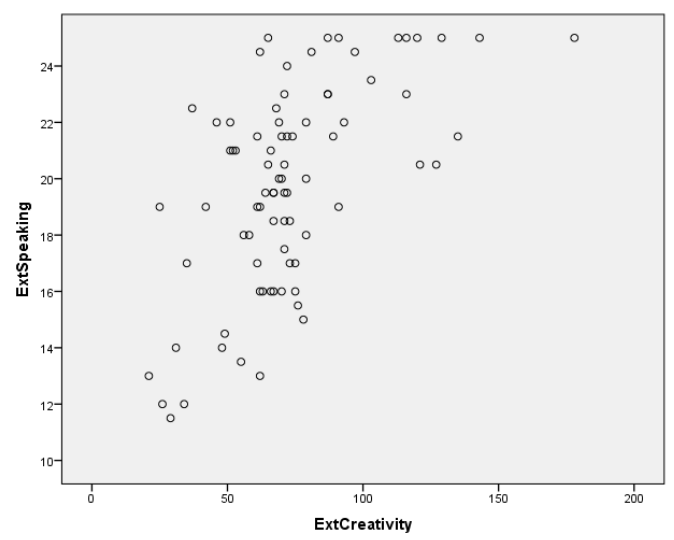

Figure 1. Scatterplot of extroverts' scores on the speaking and creativity tests

As shown in this scatterplot, there was no kind of nonlinear relationship between the scores on the two batteries. Hence, the relationship between the two variables was assumed linear. As for homoscedasticity, the researchers examined the residuals plot (Figure 2). 


\section{Hamid Marashi \& Asal Amin Ranjbar}

Creativity vis-à-vis speaking among extrovert and introvert EFL

learners

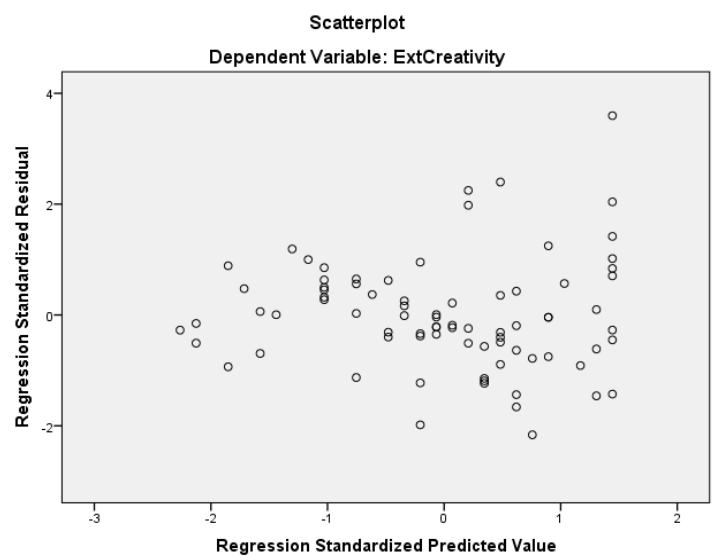

Figure 2. Plot of studentized residuals for extroverts' creativity

As demonstrated in Figure 2, the cloud of data scattered shows evenness at both ends and thus the variance is homogeneous and the principle of homoscedasticty is met (Pallant, 2007). Subsequently, the researchers could run the correlation (Table 5).

Table 5. Correlation of the extrovert participants' scores on the speaking and creativity tests

\begin{tabular}{ccc}
\hline & $\begin{array}{c}\text { Extroverts' } \\
\text { Speaking }\end{array}$ & $\begin{array}{c}\text { Extroverts' } \\
\text { Creativity }\end{array}$ \\
\hline Extroverts' Speaking & 1 & $.599 * *$ \\
Pearson Correlation &. & .000 \\
Sig. (2-tailed) & 80 & 80 \\
N & $.599 * *$ & 1 \\
Extroverts' Creativity & .000 &. \\
Pearson Correlation & 80 & 80 \\
Sig. (2-tailed) & & \\
N &
\end{tabular}

$* *$ Correlation is significant at the 0.01 level (2-tailed)

As demonstrated by Table 5 above, the correlation came out to be significant at the 0.01 level $(\mathrm{r}=0.599, p=0.0001<0.05)$. Thus the $\mathrm{R}^{2}$ (or common variance) which is the effect size for correlation came out to be 0.358 . This is a moderate effect size (Cohen, 1992; Larson-Hall, 2010). Accordingly, there is a significant relationship between extrovert EFL learners' speaking and creativity.

\section{Second Research Question}

Next, to respond to the second research question, i.e. whether a significant relationship existed between introverts learners' speaking and creativity, again the Pearson Correlation Coefficient had to be run. A scatterplot was used to inspect the linearity of the two variables of the study (Figure 3) showing there was no kind of nonlinear relationship between the scores on the two batteries. Then, Figure 4 demonstrates homoscedasticity. 


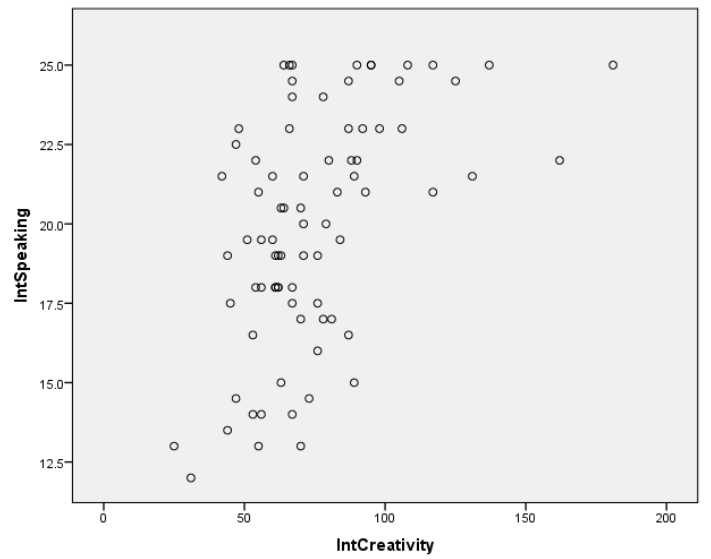

Figure 3. Scatterplot of introverts' scores on the speaking and creativity tests Scatterplot

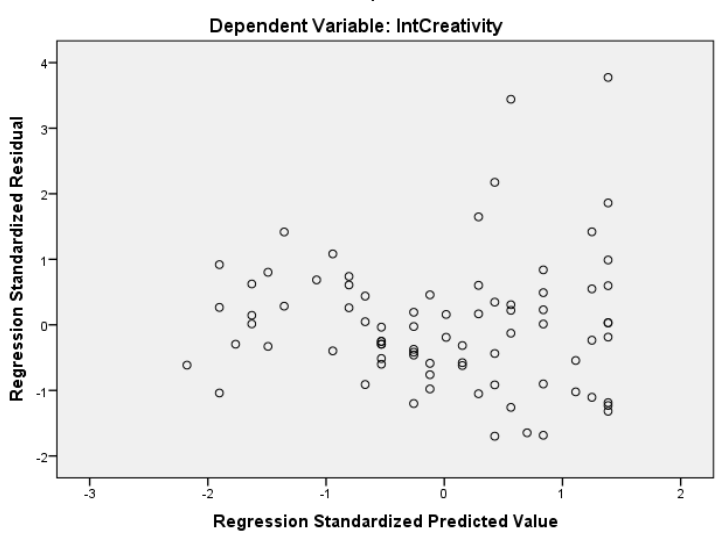

Figure 4. Plot of studentized residuals for introverts' creativity

Table 6. Correlation of introverts' scores on the speaking and creativity

\begin{tabular}{ccc}
\hline & $\begin{array}{c}\text { Introverts' } \\
\text { Speaking }\end{array}$ & $\begin{array}{c}\text { Introverts' } \\
\text { Creativity }\end{array}$ \\
\hline Introverts' Speaking & 1 & $.517^{* *}$ \\
Pearson Correlation &. & .000 \\
Sig. (2-tailed) & 80 & 80 \\
N & & \\
Introverts' Creativity & $.517^{* *}$ & 1 \\
Pearson Correlation & .000 &. \\
Sig. (2-tailed) & 80 & 80 \\
N &
\end{tabular}

**Correlation is significant at the 0.01 level (2-tailed)

As demonstrated by Table 6 above, the correlation came out to be significant at the 0.01 level $(\mathrm{r}=0.517, p=0.0001<0.05)$ and $\mathrm{R}^{2}$ came out to be 0.267 . This too is a moderate effect size (Cohen, 1992; LarsonHall, 2010). Therefore, there is a significant relationship between introvert learners' speaking and creativity.

\section{Third Research Question}

Then, to answer the third question, i.e. whether extrovert learners' creativity was a significant predictor of their speaking or not, a linear regression was run (Table 7). 


\section{Hamid Marashi \& Asal Amin Ranjbar}

Creativity vis-à-vis speaking among extrovert and introvert EFL learners

Table 7. Regression output: ANOVA table

\begin{tabular}{llccccc}
\hline & Model & Sum of squares & df & Mean square & F & Sig. \\
\hline \multirow{3}{*}{1} & Regression & 22058.493 & 1 & 22058.493 & 43.618 & $.000^{\mathrm{b}}$ \\
& Residual & 39446.495 & 78 & 505.724 & & \\
& Total & 61504.987 & 79 & & & \\
\hline
\end{tabular}

a. Predictors: (constant), Extroverts' Speaking

b. Dependent variable: Extroverts' Creativity

Table 8 demonstrates the standardized beta coefficient $(\mathrm{B}=0.599, t=6.604, p=$ $0.0001<0.05)$ which reveals that the model was significant meaning that extrovert learners' creativity could predict significantly their speaking.

Table 8. Regression output: Coefficients

\begin{tabular}{|c|c|c|c|c|c|c|}
\hline & \multirow[t]{2}{*}{ Model } & \multicolumn{2}{|c|}{$\begin{array}{l}\text { Unstandardized } \\
\text { Coefficients }\end{array}$} & \multirow[t]{2}{*}{$\begin{array}{l}\text { Standardized } \\
\text { Coefficients }\end{array}$} & \multirow[t]{2}{*}{$t$} & \multirow[t]{2}{*}{ Sig. } \\
\hline & & B & Beta & & & \\
\hline \multirow[b]{2}{*}{1} & (Constant) & -17.637 & 13.950 & & -1.264 & .210 \\
\hline & $\begin{array}{l}\text { Extroverts' } \\
\text { Creativity }\end{array}$ & 4.590 & .695 & .599 & 6.604 & .000 \\
\hline
\end{tabular}

a. Dependent variable: Extroverts' creativity

Although normality of the distributions were checked for correlation in the previous sections, the residuals table (as demonstrated in Table 9 below) also verified the absence of outstanding outliers as the Cook's distance values did not exceed 1 and Mahalanobis distance values did not exceed 15 . Hence, extrovert learners' creativity could predict significantly their speaking.

Table 9. Regression output: Residuals statistics

\begin{tabular}{|c|c|c|c|c|c|}
\hline & Minimum & Maximum & Mean & Std. Deviation & $\mathrm{N}$ \\
\hline Predicted Value & 5.0978 & 7.5172 & 6.1927 & .41371 & 80 \\
\hline Std. Predicted Value & -2.646 & 3.202 & .000 & 1.000 & 80 \\
\hline $\begin{array}{l}\text { Standard Error of Predicted } \\
\text { Value }\end{array}$ & .100 & .337 & .135 & .044 & 80 \\
\hline Adjusted Predicted Value & 4.9794 & 7.4890 & 6.1938 & .41557 & 80 \\
\hline Residual & -3.37662 & 3.22706 & .00000 & 1.43011 & 80 \\
\hline Std. Residual & -2.355 & 2.251 & .000 & .998 & 80 \\
\hline Stud. Residual & -2.362 & 2.257 & .000 & 1.003 & 80 \\
\hline Deleted Residual & -3.39648 & 3.24348 & -.00112 & 1.44712 & 80 \\
\hline Stud. Deleted Residual & -2.389 & 2.280 & .000 & 1.007 & 80 \\
\hline Mahalanobis Distance & .001 & 10.250 & .995 & 1.570 & 80 \\
\hline Cook's Distance & .000 & .099 & .006 & .013 & 80 \\
\hline Centered Leverage Value & .000 & .050 & .005 & .008 & 80 \\
\hline
\end{tabular}

a. Dependent Variable: Extroverts' creativity

\section{Fourth Research Question}

Lastly, to respond to the fourth question, i.e. whether introvert learners' creativity was a significant predictor of their speaking or not, a linear regression was run. Table 10 reports the results of the ANOVA $\left(\mathrm{F}_{1,78}=28.507, p=\right.$ $0.0001<0.05)$ which proved significant. 
Table 10. Regression output: ANOVA table

\begin{tabular}{clccccc}
\hline & Model & Sum of squares & Df & Mean square & F & Sig. \\
\hline \multirow{2}{*}{1} & Regression & 15051.217 & 1 & 15051.217 & 28.507 & $.000^{\mathrm{b}}$ \\
& Residual & 41182.983 & 78 & 527.987 & & \\
& Total & 56234.200 & 79 & & & \\
\hline
\end{tabular}

a. Predictors: (constant), Introverts' speaking

b. Dependent variable: Introverts' creativity

Table 11 demonstrates the standardized beta coefficient $(\mathrm{B}=0.517, t=5.339, p=$ $0.0001<0.05)$ which reveals that the model was significant meaning that introvert learners' creativity could predict significantly their speaking. Then, Table 12 below also verified the absence of outstanding outliers as the Cook's distance values did not exceed 1 and Mahalanobis distance values did not exceed 15.

Table 11. Regression output: Coefficients

\begin{tabular}{|c|c|c|c|c|c|c|}
\hline & \multirow[t]{2}{*}{ Model } & \multicolumn{2}{|c|}{$\begin{array}{l}\text { Unstandardized } \\
\text { Coefficients }\end{array}$} & \multirow[t]{2}{*}{$\begin{array}{l}\text { Standardized } \\
\text { Coefficients }\end{array}$} & \multirow[t]{2}{*}{$t$} & \multirow[t]{2}{*}{ Sig. } \\
\hline & & B & Beta & & & \\
\hline \multirow{2}{*}{1} & (Constant) & -.287 & 14.361 & & -.020 & .984 \\
\hline & Introverts' AQ & 3.782 & .708 & .517 & 5.339 & .000 \\
\hline
\end{tabular}

Table 12. Regression output: Residuals statistics

\begin{tabular}{lccccc}
\hline & Minimum & Maximum & Mean & Std. Deviation & $\mathrm{N}$ \\
\hline Predicted Value & 45.10 & 94.28 & 75.15 & 13.803 & 80 \\
Std. Predicted Value & -2.177 & 1.386 & .000 & 1.000 & 80 \\
Standard Error of Predicted & 2.569 & 6.186 & 3.520 & .906 & 80 \\
Value & 46.20 & 95.43 & 75.12 & 13.806 & 80 \\
Adjusted Predicted Value & -39.037 & 86.725 & .000 & 22.832 & 80 \\
Residual & -1.699 & 3.774 & .000 & .994 & 80 \\
Std. Residual & -1.712 & 3.846 & .001 & 1.007 & 80 \\
Stud. Residual & -39.623 & 90.038 & .035 & 23.445 & 80 \\
Deleted Residual & -1.733 & 4.244 & .010 & 1.043 & 80 \\
Stud. Deleted Residual & .000 & 4.739 & .987 & 1.068 & 80 \\
Mahalanobis Distance & .000 & .283 & .013 & .035 & 80 \\
Cook's Distance & .000 & .060 & .013 & .014 & 80 \\
Centered Leverage Value & & & & &
\end{tabular}

a. Dependent Variable: Introverts' creativity

\section{DISCUSSION}

The findings of the present study are in line with those of Baghaei and Bagheri (2012) who found a significantly positive relationship between creativity and speaking skill among Iranian IELTS candidates. This study also revealed that there was a significant relationship between introvert EFL learners' speaking and creativity; that is, the higher the level of introvert EFL learners' speaking, the higher their creativity and vice versa. A possible explanation for the above finding might be the fact that instead of just blurting out the word, introverts think before expressing any idea or any feeling they have (Sharp, 1987) and due to this reflection process, which reoccurs on a daily basis, their creativity and speaking ability are related. In other words, it can be stated that since introverts reflect upon their utterances several times, they have the ability to produce original, novel ideas which as pointed out by Shomoossi and Majidi Fard (2013), moderately influence how learners perform orally. 
One possible justification for the findings of the present study in this respect, as rightly pointed out by Khany and Ghoreyshi (2013), is that "Extroverted learners prefer to engage more in social activities and tasks in the classroom; thus this preference helps them improve their level of speaking confidence" (p. 606). Moreover, extroverts are carefree, energetic, and friendly and they are constantly looking for change and new ideas in their lives, and consequently invent or make use of different strategies to communicate orally with other individuals. For instance, Ehrman and Oxford (1990) state that extroverts prefer functional practice strategies such as looking for practice opportunities outside of class and social strategies such as asking for clarification.

\section{CONCLUSION}

Teachers may benefit from being creative in teaching. If teachers are not creative themselves, it would be difficult to develop this feature among their students. Another point is that teachers perhaps need to pay attention to learners' personality attributes when it comes to attempting to boost their creativity. So, it seems necessary to do research on the creativity of extrovert and introvert learners. Accordingly, the present study can help learners learn about their intellectual strengths and weaknesses. It might be able to help learners develop themselves.

In the process of conducting this study, the researchers came across certain points that can be further investigated. First of all, this study can be replicated with different age groups. Secondly, demographic features such as socioeconomic background and ethnicity were not controlled in this study; further studies could be conducted while controlling such variables.

\section{REFERENCES}

Abedi, J. (2002). Standardized achievement test and English language learners: Psychometric issues. Educational Assessment, 8, 231-257.

Amabile, T. M., \& Khaire, M. (2008). Creativity and the role of the leader. Harvard Business Review, 86, 100-109.

Aragon, S. R., Johnson, S. D., \& Shaik, N. (2002). The influence of learning style preferences on student success in online versus face-to-face environments. The American Journal of Distance Education, 16(4), 227-244.

Averill, J. (2004). A tale of two snarks: Emotional intelligence and emotional creativity compared. Psychological Inquiry, 15, 228-233.

Baer, J. (2010). Is creativity domain specific? In J. C. Kaufman \& R. J. Sternberg (Eds.), The Cambridge handbook of creativity (pp. 321-341). New York: Cambridge University Press.

Baghaei, S., \& Bagheri, M. S. (2012). The relationship between verbal creativity and speaking skill of IELTS candidates. Iranian EFL Journal, 9(4), 299-310.

Bijani, H., \& Khabiri, M. (2017). Direct and semi-direct validation: Test takers' perceptions, evaluations and anxiety towards speaking module of an English proficiency test. Journal of Language and Translation, 7(13), 25-41.

Brown, H. D. (2001). Teaching by principles: An interactive approach to language pedagogy. New York: Pearson Education.

Burger, J. M. (1993). Personality. Pacific Grove, CA: Brooks-Cole.

Burruss, J. D., \& Kaenzig, L. (1999). Introversion: The often forgotten factor impacting the gifted. Virginia Association for the Gifted Newsletter, 21(1), 1-4.

Canale, M., \& Swain, M. (1980). Theoretical bases of communicative approaches to second language teaching and testing. Applied Linguistics, 1(1), 147.

Chaney, A. L., \& Burk, T. L. (1998). Teaching oral communication in grades $K-8$. Boston, MA: Allyn \& Bacon.

Chuang, Y. Y. (2009). Foreign language speaking assessment: Taiwanese college English teachers' scoring performance in the holistic and analytic rating methods. Asian EFL Journal, 11(1), 150173.

Cohen, J. (1992). Statistical power analysis for the behavioral sciences (2nd ed.). Hillsdale, NJ: LEA.

Cope, C. (2008). Linguistic structure and personality development. Journal of Counseling Psychology, 16, 1-19.

Cropley, A. (2007). Using assessment to foster creativity. In A. G. Tan (Ed.), Creativity. A handbook for teachers (pp. 209-230). Singapore: World Scientific.

Daemi, H., \& Moghimi, S. F. (2004). Standardization of creativity test. Advances in Cognitive Science, 24, 1-8.

Dewaelea, J. M., \& Furnham, A. (2000). Personality and speech production: A pilot study of second language learners. Personality and Individual Differences, 28, 355-365.

Davis, G. A. (1999). Barriers to creativity and creative attitudes. In M. A. Runco \& S. R. Pritzker (Eds.), Encyclopedia of creativity: Vol. 1 (pp. 165-174). San Diego, CA: Academic Press. 
Dimler, M., Goldstein, L. Kohlberger, B., \& KimPrieto, C. (2007). Introversion. In R. Baumeister \& K. Vohs (Eds.), Encyclopedia of social psychology (pp. 503-504). Thousand Oaks, CA: Sage.

Downing, K. (2010). Personality and online learning. In S. Mukerji \& P. Tripathi (Eds.), Cases on interactive technology environments and transnational collaboration: Concerns and perspectives (pp. 126-139). Hershey, PA: Information Science Reference.

Ehrman, M., \& Oxford, R., (1990). Adult language learning styles and strategies in an intensive training setting. Modern language Journal, 74, 311-326.

Ellis, R. (1994). The study of second language acquisition (2nd ed.). London: Sage publications.

Eysenck, S. B. G., Eysenck, H. J., \& Barrett, P. (1985). A revised version of the psychoticism scale. Journal of Personality \& Individual Differences, 6(1), 21-29.

Hedge, T. (2008). Teaching and learning in the language classroom. Oxford: Oxford University Press.

Hymes, D. (1972). On communicative competence. In J. B. Pride \& J. Holmes (Eds.), Sociolinguistics: Selected readings (pp. 269-293). Harmondsworth: Penguin.

Jeffery, B., \& Craft, A. (2001). Introduction: The universalization of creativity. In A. Craft, B. Jeffery, \& M. Leibling (Eds.). Creativity in education (pp. 1-16). London: Continuum.

John, E. B., \& Meera, K. P. (2014). Effect of cooperative learning strategy on the creative thinking skills of secondary school students of Kozhikode District. IOSR Journal of Humanities and Social Science, 19(11), 70-74.

Kellogg, R. T. (1994). The psychology of writing. Oxford: Oxford University Press.

Khany, R. \& Ghoreyshi, M. (2013). The nexus between Iranian EFL students' big five personality traits and foreign language speaking confidence. European Online Journal of Natural and Social Science (special Issue on teaching and learning), 2(2), 601-611.

Kim, H. (2009). The role of grammar in speaking proficiency: Exploring the need for spoken grammar. Modern English Education, 10(1), 4665.

Koosha, B., Ketabi, S., \& Kassaian, Z. (2011). The effects of self-esteem, age, and gender on the speaking skill of intermediate university EFL learners. Theory and Practice in Language Studies, 1(10), 1328-1337.

Larson-Hall, J. (2010). A guide to doing statistics in second language research using SPSS. New York: Routledge Publishing.

Lucas, R. E. (2007). Extraversion. In R. Baumeister \& K. Vohs (Eds.), Encyclopedia of social psychology (pp. 334-335). Thousand Oaks, CA: Sage.
Marashi, H., \& Dadari, L. (2012). The impact of using task-based writing on EFL learners' writing performance and creativity. Theory and Practice in Language Studies, 2(12), 2500-2507.

Marashi, H., \& Dibah, P. (2013). The comparative effect of using competitive and cooperative learning on the oral proficiency of Iranian introvert and extrovert EFL learners. Journal of Language Teaching and Research, 4(3), 545-555.

Marashi, H., \& Dolatdoost, M. (2016). ADHD and adolescent EFL learners' complexity, accuracy, and fluency. Iranian Journal of Language Teaching Research, 4(2), 105-126.

Marashi, H., \& Fotoohi, M. (2017). The relationship between extrovert and introvert EFL teachers' adversity quotient and professional development. Journal of Applied Linguistics and Language Research, 4(3), 156-170.

Marashi, H., \& Khatami, H. (2017). Using cooperative learning to boost creativity and motivation in language learning. Journal of Language and Translation, 7(1), 43-58.

Morrone-Strupinsky, J. V., \& Lane, R. D. (2007). Parsing positive emotion in relation to agentic and affiliative components of extroversion.

Personality and Individual Differences, 42, $1267-$ 1278.

O’Neil, H. F., Abedi, J., \& Spielberger, C. D. (1992). The measurement and teaching of creativity. In $\mathrm{H}$. F. O’Neil \& M. Drillings (Eds.), Motivation: Theory and research (pp. 245-264). Hills dale, NJ: Lawrence Erlbaum Associates.

Pallant, J. (2007). Survival manual: A step by step guide to data analysis using SPSS for Windows. Sydney, Australia: Allen \& Unwin.

Richards, J. C., \& Schmidt, R. (2002). Longman dictionary of language teaching and applied linguistics. London: Pearson.

Runco, M. A. (2004). Creativity. Annual Review of Psychology, 55, 657-687.

Sarsani, M. R. (2006). Creativity in schools. New Delhi: Sarup \& Sons.

Shackleton, V., \& Fletcher, C. (1984). Individual differences: Theories and applications. London: Methuen.

Sharp, D. (1987). Personality types: Jung's model of typology. Toronto: University of Toronto Press.

Shomoossi, N., \& Majidi Fard, E. (2013). Creativity and oral narrative proficiency in Persian learners of English. Life Science Journal, 10(5), 460-465.

Silvia, P. J. (2008). Discernment and creativity: How well can people identify their most creative ideas? Psychology of Aesthetics, Creativity, and the Arts, 2, 139-146.

Sternberg, R. J., \& Kaufman, J. C. (2010). The Cambridge handbook of creativity. New York: Cambridge University Press.

Sternberg, R. J., \& Lubart, T. I. (1996). Investing in creativity. American psychologist, 51(7), 677-688. 


\section{Hamid Marashi \& Asal Amin Ranjbar}

Creativity vis-à-vis speaking among extrovert and introvert EFL learners

Thompson, S. (2012). Introvert? Extrovert? Tips for a balanced classroom. Canadian Teacher Magazine, 10(8), 6-8.

Thornbury, S. (2005). Natural grammar: The keywords of English and how they work. New York: Oxford University Press.

Tuan, T. A., \& Neomy, S. (2007). Investigating group planning in preparation for oral presentations. RELC Journal, 38(1), 104-124.

Vercellotti, M. L. (2015). The development of complexity, accuracy, and fluency in second language performance: A longitudinal study. Applied Linguistics, 36(2), 1-25.

Zafar, S., \& Meenakshi, K. (2012). A study on the relationship between extroversion-introversion and risk-taking in the context of second language acquisition. International Journal of Research Studies in Language Learning, 1(1), 33-40.

Zuckerman, M. (2005). Psychology of personality. Cambridge: Cambridge University Press. 